7 Kaminetzky, H., Obstet. and Gynec, , 27, 489 (1966).

${ }^{8}$ Glücksmann, A., and Cherry, C., Brit. J. Cancer, 16, 634 (1962)

9 Maqueo, M., Azuela, J. C., Calderon, J. J., and Goldzieher, J. W. Amer.J. Obstet. Gynec., 96, 994 (1966).

10 Govan, A. D. T., Black, W. P., and Sharp, J. L., J. Clin. Path., 22 84 (1969).

\section{Cholera Enterotoxin: Failure of Anti-inflammatory Agents to Prevent Cyclic AMP Accumulation}

THERE is considerable evidence that cholera diarrhoea is caused by accumulation of cyclic AMP in intestinal mucosa, stimulated by cholera enterotoxin ${ }^{1-3}$. Prostaglandin- $E_{1}$ $\left(\mathrm{PGE}_{1}\right)$ reproduces the effects of cholera enterotoxin on both cyclic AMP and secretion of fluid and electrolytes by intestinal mucosa ${ }^{3}$ and it was suggested ${ }^{4}$ that the toxin might first act by stimulating the release or synthesis of prostaglandin which then acts through cyclic AMP. Bennett $t^{4}$ proposed that acidic anti-inflammatory drugs, as they are potent inhibitors of prostaglandin synthesis in several tissues ${ }^{5-7}$, might antagonize the effect of cholera enterotoxin. Jacoby and Marshall reported that indomethacin, aspirin, and several other anti-inflammatory agents inhibited the cholera toxininduced accumulation of fluid in ileal-ligated rats ${ }^{8}$. Because of its potential therapeutic significance, I have studied this proposed mechanism.

The cyclic AMP system is stimulated by cholera enterotoxin in virtually every tissue so far tested, including liver, adipose tissue, and blood platelets, in addition to intestinal mucosa $^{1,9-11}$. Low concentrations $\left(1-10 \mathrm{ng} \mathrm{ml}{ }^{-1}\right)$ of the purified toxin increased adenyl cyclase activity and cyclic AMP accumulation in human leucocytes ${ }^{12,13}$, and this effect was similar in all respects to that on intestinal mucosa, including toxin concentration required, the characteristically delayed time-course, and specific inhibition by cholera toxoid and a canine antitoxin. The leucocyte seemed a suitable tissue for testing Bennett's suggestion in vitro, as $\mathrm{PGE}_{1}$ also stimulates leucocyte cyclic AMP accumulation ${ }^{13-15}$.

Leucocytes of three healthy human volunteers were prepared as described previously and suspended in a Trisbuffered salt solution containing $0.3 \%(\mathrm{w} / \mathrm{v})$ human serum albumin $^{14}$. Leucocytes $\left(1 \times 10^{7} \mathrm{ml} .^{-1}\right)$ and purified cholera enterotoxin $10 \mathrm{ng} \mathrm{ml} .^{-1}$, a maximally effective concentra$\operatorname{tion}^{12}$ ) were incubated for $90 \mathrm{~min}$ at $37^{\circ} \mathrm{C}$. Varying concentrations of indomethacin or aspirin were added to leucocytes $5 \mathrm{~min}$ before addition of cholera toxin. Incubation was terminated by centrifugation $(2,000 \mathrm{~g}$ for $1 \mathrm{~min})$, after which the supernatant fluid was discarded and the cell button resuspended in ice-cold 5\% trichloroacetic acid. Leucocyte cyclic AMP was then assayed by the competition-binding method of Gilman ${ }^{16}$, modified as described previously ${ }^{15}$.

Table 1 Leucocyte Cyclic AMP after Exposure to Anti-inflammatory Agents and Cholera Enterotoxin

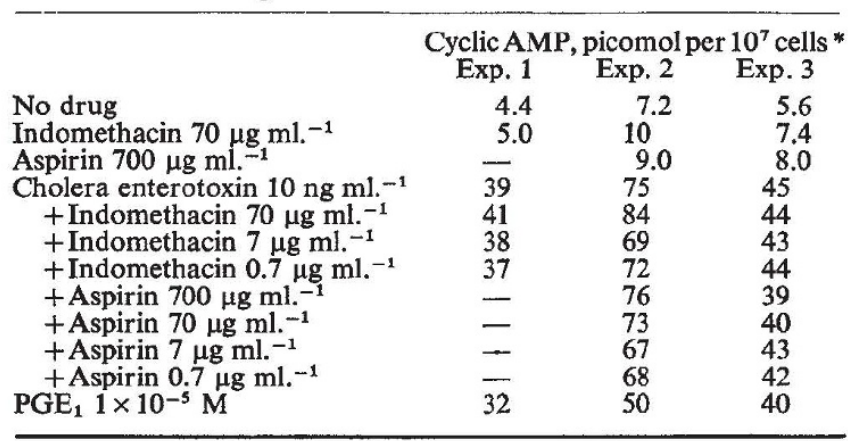

* Each value is the mean of duplicates differing by $\pm 8 \%$.
Neither aspirin nor indomethacin produced any detectable inhibition of the eight-fold increase in leucocyte cyclic AMP caused by cholera enterotoxin (Table 1). $\mathrm{PGE}_{1}$ alone caused accumulation of cyclic AMP, as described previously ${ }^{13-15}$. The maximal concentrations of both anti-inflammatory agents were considerably higher than those which produced complete inhibition of prostaglandin synthesis in guinea-pig lung $^{5}$ and canine spleen ${ }^{7} ; 3-4 \mu \mathrm{g} \mathrm{ml} .^{-1}$ for indomethacin and $30-40 \mu \mathrm{g} \mathrm{ml} .^{-1}$ for aspirin.

The similarities between cholera enterotoxin's effects on the cyclic AMP content of gut mucosa and leucocytes suggest that the toxin's mechanism of action may be similar in the two tissues. If so, high concentrations of aspirin and indomethacin would not be expected to prevent accumulation of cyclic AMP in gut mucosa exposed to maximally effective doses of cholera enterotoxin. This possibility must be tested directly with maximally-and submaximally-effective doses of cholera toxin on the gut mucosa, and it must be shown in both leucocytes and mucosa that indomethacin and aspirin greatly reduce prostaglandin synthesis. The present results show that cholera toxin alone can increase cyclic AMP levels maximally in human leucocytes. They do not exclude the possibility that the gut behaves differently or that a dual mechanism exists. In addition to the direct action of toxin there might be an indirect effect involving prostaglandins, and this would become evident only in experiments with the submaximal doses of toxin. Nevertheless, increased synthesis of prostaglandin is unlikely to prove a universal mechanism for the actions of cholera enterotoxin, since the toxin (like cyclic AMP) stimulates lipolysis in adipocytes ${ }^{9}$, cells in which PGE $_{1}$ inhibits both cyclic AMP accumulation and lipolysis ${ }^{17,18}$.

These results do not preclude a beneficial therapeutic effect of acidic anti-inflammatory agents in cholera. The inhibition of toxin-induced intestinal fluid accumulation by these agents in vivo ${ }^{8}$ deserves further investigation, even if it belongs to a class of drug effects in which cyclic AMP plays no role.

I thank Sally Dion for technical assistance, and the United States Public Health Service and the American Heart Association for support. The purified toxin was obtained from Dr W. B. Greenough, III.

\section{H. R. BOURNE}

Departments of Medicine and Pharmacology,

University of California Medical Center,

San Francisco, California 94122

Received September 11, 1972.

1 Pierce, N. F., Greenough, W. B., III, and Carpenter, C. C. J., jun., Bacteriol. Rev. 35, 1 (1971).

${ }^{2}$ Schafer, D. E., Lust, W. D., Sirear, B., and Goldberg, N. D., Proc. US Nat. Acad. Sci., 67, 85 (1970).

3 Kimberg, D. V., Field, M., Johnson, J., Henderson, A., and Gershon, E., J. Clin. Invest., 50, 1218 (1971).

4 Bennett, A., Nature, 231, 536 (1971).

5 Vane, J. R., Nature New Biology, 231, 232 (1971).

6 Smith, J. B., and Willis, A. L., Nature New Biology, 231, 235 (1971).

${ }^{7}$ Ferreira, S. H., Moncada, S., and Vane, J. R., Nature New Biology, 231, 237 (1971).

8 Jacoby, H. I., and Marshall, C. H., Nature, 235, 163 (1972).

9 Vaughan, M., Pierce, N. F., and Greenough, W. B., III, Nature, 226, 658 (1970)

${ }^{10}$ Zieve, P. D., Pierce, N. F., and Greenough, W. B., III, Clin. Res., 18, 690 (1970).

11 Gorman, R. E., and Bitensky, M. W., Nature, 235, 439 (1972).

12 Lichtenstein, L. M., Bourne, H. R., and Henney, C. S., J. Clin. Invest. (in the press).

13 Bourne, H. R., Lehrer, R. I., Lichtenstein, L. M., Weissman, G., and Zurier, R., J. Clin. Invest. (in the press).

14 Bourne, H. R., and Melmon, K, L., J. Pharm. Exp. Ther., 178, 1 (1971).

15 Bourne, H. R., Lichtenstein, L. M., and Melmon, K. L., J. Immunol., 108, 695 (1972).

16 Gilman, A. G., Proc. US Nat. Acad. Sci., 67, 305 (1970).

17 Steinberg, D., Vaughan, M., Nestel, P. J., Strand, O., and Bergstrom, S., J. Clin. Invest., 43, 1533 (1964).

18 Butcher, R. W., and Baird, C. E., J. Biol. Chem., 243, 1713 (1968). 